\title{
Editorial: Expansive Learning in Teacher Education
}

\author{
Ainat Guberman ${ }^{1,2 *}$ and Kari Smith ${ }^{3}$ \\ ${ }^{1}$ David Yellin College of Education, Jerusalem, Israel, ${ }^{2}$ The Mofet Institute, Tel-Aviv, Israel, ${ }^{3}$ Norwegian University of Science and \\ Technology, Trondheim, Norway
}

Keywords: expansive learning, teacher education, teacher educators, professional development, innovation

\section{Editorial on the Research Topic}

\section{Expansive Learning in Teacher Education}

The quality of teaching plays a central role in preparing today's children for participation in a rapidly changing world. Subsequently, the quality of teacher education is a pre-requisite in the education of teachers for today and the future (European Commission, 2013). Acknowledging that traditional work methods and knowledge transmission no longer suffice, groundbreaking innovations are sought. "Expansive Learning" is a term coined by Engeström (Engeström and Sannino, 2010) to describe the creation of new professional knowledge, as opposed to learners' acquisition of existing knowledge previously unknown to them. This special issue deals with expansive learning in teacher education.

Engeström and Sannino (2020) describe four generations of cultural-historical activity theory. In its simplest form, activity is a culturally mediated action such as teaching. Second generation activity theory analyzes relatively durable systems such as schools, that are oriented toward a meaningful societal goal. Activity systems have norms, tools and division of labor. Two or more activity systems that have a partially shared object are the unit of analysis for third-generation activity theory.

\section{OPEN ACCESS}

Edited and reviewed by: Stefinee Pinnegar, Brigham Young University, United States

${ }^{*}$ Correspondence: Ainat Guberman ainatgub@gmail.com

Specialty section: This article was submitted to Teacher Education, a section of the journal

Frontiers in Education

Received: 18 April 2021 Accepted: 22 June 2021 Published: 07 July 2021

Citation:

Guberman A and Smith K (2021) Editorial: Expansive Learning in Teacher Education.

Front. Educ. 6:696965. doi: 10.3389/feduc.2021.696965
Partnerships between higher education institutions and schools in initial teacher education are an example. Finally, fourth-generation activity theory deals with large numbers of activity systems that jointly attempt to resolve global issues.

Expansive learning involves a three-pronged change: transformed practices, novel theoretical conceptualizations, and an empowered sense of agency. Expansive learning is often a social, and not merely an individual change, and it transforms all aspects of the learning organizations' professional activity: its vision and goals, practices or products. Learning develops gradually in cyclical processes in the learning organizations' 'proximal development zone' (Vygotsky, 1978). A new circle opens when existing, stable achievements which were formed in previous cycles are called into question. The outcome is not guaranteed. The process is fraught with misunderstandings, lacunae, conflicts, and unexpected outcomes. It is heavily influenced by the personal characteristics of the participants, their existing knowledge and goals, and their values, emotions and habits. However, failed attempts may become a source of learning and inspiration for others (Engeström and Sannino, 2010; Sannino et al., 2016).

This special issue presents studies of projects in teacher education that attempt to transform accepted practices and conceptualizations at different levels: from individual teacher educators and institutions to international collaborations. Our aim with this issue is that it will contribute to the collective effort to provide teacher educators, teachers and students with new insights and knowledge about expansive learning.

The paper "Teacher Educators and Expansive Learning in the Workplace and Beyond", authored by Jean Murray, Warren Kidd, Andrea McMahon, and Sheeba Viswarajan describes how a professional learning experience of teacher educators generated sustained changes in teaching 
and research practices within their institution, as well as in their own sense of agency and professional identity.

Three papers explore the relationships between schools and teacher education institutions and align with third generation activity theory. The paper "Expansive Learning within a Teachers Community of Ongoing Learners (TCOOL)", authored by Frances Rust, Meghan Dunn and Sabrina Silverstein presents the first iteration of a project designed to prepare teachers for high poverty urban schools. As the teacher education institution and the school attempted to collaborate, they had to change their practices and deviate from their original plans. These led to new theoretical insights.

May Britt Postholm's paper "Premises and Promises for Expansive Learning in Teacher Education" describes how teacher educators' involvement in the professional development of schools resulted in changes in both types of institutions. However, teacher educators' learning was largely restricted to those who were actively involved in the project.

The paper "Expansive Learning in Teacher Education's Hybrid Spaces: The Challenges and Possibilities in and Beyond Learning Studios", authored by Jeroen Imants, Paulien C. Meijer and Erik Blankesteijn reports that the expansive learning that had occurred in "learning studios" was barely disseminated to other teachers. Neither was it disseminated beyond the higher education institution directly involved in the studios. Both papers attempt to identify factors that can either impede or enhance teacher educators' learning.

Two papers represent the national level and lie between thirdand fourth-generation activity theory: On the one hand, they deal with persistent problems that concern numerous countries. On the other hand, the national scope restricts the stakeholders to identifiable and relatively stable groups. Marit Ulvik's paper

\section{REFERENCES}

Engeström, Y., and Sannino, A. (2020). From Mediated Actions to Heterogenous Coalitions: Four Generations of Activity-Theoretical Studies of Work and Learning. Mind, Cult. Activity 28, 4-23. doi:10.1080/10749039.2020.1806328

Engeström, Y., and Sannino, A. (2010). Studies of Expansive Learning: Foundations, Findings and Future Challenges. Educ. Res. Rev. 5, 1-24. doi:10.1016/j.edurev.2009.12.002

European Commission (2013). Supporting Teacher Educators for Better Learning Outcomes. Brussels: European Commission.

Sannino, A., Engeström, Y., and Lemos, M. (2016). Formative Interventions for Expansive Learning and Transformative agency. J. Learn. Sci. 25 (4), 599-633. doi:10.1080/10508406.2016.1204547
"Promoting Aesthetical Values to Education" asserts that the aesthetic dimension should be incorporated into disciplinary studies in secondary schools, as it can raise students' motivation, engagement and creativity, and it contributes to students' meaning-making and emotional wellbeing.

The paper "Expansive Learning in Inter-Institutional Communities of Practice for Teacher Educators and Policymakers" is authored by Ainat Guberman, Orit AvidovUngar, Orit Dahan and Ruth Serlin. It describes how collaboration between teacher educators and policymakers resulted in transformed practices in three areas: providing support to students with special needs, fostering partnerships between teacher educating institutions and schools, and devising "Multi-player Induction Teams" in which teacher educators, mentor teachers, beginning teachers and additional stakeholders collaborate to support beginning teachers' induction.

Finally, Kari Smith's paper “Expansive Learning for Teacher Educators-The Story of the Norwegian National Research School in Teacher Education (NAFOL)" describes a national initiative with an international impact. NAFOL was established to develop research-based teacher education and strengthen teacher educators' research competence by supporting teacher educators engaged in doctoral studies. Internationalization is an important aspect of the research school, and the model as a whole can inspire teacher educators' expansive learning worldwide.

\section{AUTHOR CONTRIBUTIONS}

All authors listed have made a substantial, direct, and intellectual contribution to the work and approved it for publication.

Vygotsky, L. S. (1978). Mind in Society. Cambridge, Massachusetts, London, England: Harvard University Press.

Conflict of Interest: The authors declare that the research was conducted in the absence of any commercial or financial relationships that could be construed as a potential conflict of interest.

Copyright (C) 2021 Guberman and Smith. This is an open-access article distributed under the terms of the Creative Commons Attribution License (CC BY). The use, distribution or reproduction in other forums is permitted, provided the original author(s) and the copyright owner(s) are credited and that the original publication in this journal is cited, in accordance with accepted academic practice. No use, distribution or reproduction is permitted which does not comply with these terms. 